\title{
The classification of private foundations for US federal income tax purposes
}

\section{Patrick Schmutz*}

\begin{abstract}
Professionals providing cross-border estate planning advice need to know whether a private foundation will be treated as a foreign corporation, partnership or trust for US federal income tax purposes. The present article contains a detailed evaluation of the classification possibilities of private foundations under US tax law.
\end{abstract}

\section{Introduction}

Private foundations ${ }^{1}$ are not commonly used by estate planning professionals advising citizens or residents of the United States. However, subsequent changes in the residence or citizenship of the founders or beneficiaries of foreign private foundations or investments made by private foundations in US situs assets can cause these entities to be subject to US federal income tax. Professionals providing cross-border estate planning advice thus need to know whether a private foundation, which is considered to be a legal entity in the jurisdiction where it is established and domiciled, will be treated as a foreign corporation, partnership or trust for US federal income tax purposes. If private foundations are classified as corporations, then the US tax and reporting obligations associated with foreign corporations, including the controlled foreign corporation, foreign personal holding company, and/or passive foreign

* Patrick Schmutz, LLM (Taxation) is a Swiss Attorney at Law practising at Niederer Kraft \& Frey in Zurich, Switzerland.

$\mathrm{He}$ is also admitted as a Solicitor of the Supreme Court of England and Wales, The above article is based on a paper the author wrote while attending the graduate tax program of the University of Florida. It is an attempt by a civil law practitioner to shed light on the US tax consequences of this interesting legal entity, which is little known in the US.

1 The term 'private foundation' refers to foundations established in Liechtenstein, Panama, Curacao or in other low-tax jurisdictions for non-charitable purposes. Despite their identical name, the private foundations discussed in this article are not the equivalent of the 'private foundation' of s509 Internal Revenue Code since private foundations can be used for the benefit of the founder, family members and other beneficiaries, whereas the 'private foundation' of s509 must meet the requirements of s501(c)(3), requiring strict public purposes. investment company rules, apply, if the private foundation has an actual or deemed owner who is a 'United States person'. If, however, private foundations are treated as trusts, then the rules governing the income taxation of foreign trusts created by US persons (outbound trusts) and trusts created by non-US persons for US beneficiaries (inbound trusts) will have to be applied.

By analysing the leading case on the classification of private foundations and assessing the Entity Classification Regulations, the following article provides guidance on the classification of private foundations pursuant to the provisions of the US Internal Revenue Code. ${ }^{2}$

\section{A brief analysis of the leading case on the classification of private foundations: Oei Tjong Swan's Estate v C.I.R}

The issue, how a private foundation should be classified, has been addressed by the United States Court of Appeals Second Circuit in the case 'Oei Tjong Swan's Estate v. C.I.R.' in 1957. ${ }^{3}$ The Court of Appeals decision and the appealed Tax Court decision, ${ }^{4}$ which was upheld by the Court of Appeals with regard to the classification of a foundation as a trust, are no longer decisive for the classification of private foundations, as the Entity Classification Regulations under section 7701 I.R.C. ${ }^{5}$ now define what constitutes a 'trust' for US tax law. A non-resident non-citizen making a revocable lifetime transfer of US situs assets to a foreign private foundation will, however, still face the same tax consequences and insofar the decision is very illustrative and the merits are to be briefly discussed:

\section{(i) The principle issue}

The principle issue presented for consideration by the court was whether deposits of cash and securities in a US bank by a non-resident alien, not engaged in business in the United States at the time of his death, in the

2 Unless otherwise stated, all statutory references are to the US Internal Revenue Code.

3247 F.2d 144.

4 Estate of Swan v C.I.R., 24 T.C. 829, 1955 WL 627 (Tax Ct.).

5 Section 301.7701-4(a), which came into effect on 1 January 1961. 
accounts of two family foundations established by him were includible in his gross estate for federal estate tax purposes. ${ }^{6}$

(ii) Tax consequences of revocable lifetime transfers under current law

Upon death of a non-resident non-citizen, only the part of that decedent's gross estate that is situated in the United States is included in the value of the noncitizen's gross estate. ${ }^{7}$ However, any property of which the decedent has made a transfer, by trust or otherwise, within the meaning of sections 2035 to 2038, is deemed to be situated in the United States, if so situated either at the time of the transfer or at the time of the decedent's death. ${ }^{8}$ By reference to section 2038, this provision provides that the value of a non-resident non-citizen's gross estate shall include the value of all property transferred by the decedent by trust or otherwise where the decedent up to the date of his death retained the power, 'to alter, amend, revoke, or terminate, ${ }^{9}$

(iii) Arguments of the taxpayer

The taxpayer argued that the foundations should be treated as foreign corporations and that transfers to them do therefore not fall within section 811 (d) (now Internal Revenue Code of 1954 section 2038). $\mathrm{He}$ pointed to such characteristics, inter alia, as (a) perpetual existence; (b) the capacity to engage in business; (c) treatment as a separate legal entity under the applicable foreign law; and (d) being taxed solely on their own income.

Furthermore, the taxpayer contended that the US assets of the foundations were not includible in the decedent's gross estate on the theory that the foundations would have to be considered foreign corporations, and that the instruments representing the decedent's interest in the foundations (the articles of foundation) were at the date of the decedent's death physically situated outside the United States. The taxpayer argued that although stock was not issued by the foundations, these incorporated entities should be treated as foreign corporations and consequently the instrument of organization (the articles of the foundation) received by the decedent should be considered as stock. Thus, the taxpayer argued that the transfers of the decedent's

\footnotetext{
6 Pursuant to section 862(b) of the Internal Revenue Code of 1939 (now Internal Revenue Code of 1954 section 2104(b).

7 Section 2103

8 Section 2104(b).

9 Section 2038(a)(1)
}

property to the foundations had been for valuable consideration and thus outside of the scope of sections $811(\mathrm{~d})$ or $862(\mathrm{~b}) .^{10}$

\section{(iv) Decisions of the courts}

The tax court considered the respective foundations to be very much like private trusts and held that the transfers of property by the decedent to the foundations subject to the power of revocation should not be treated any differently than transfers to a private trust. In the court's view, it was relatively insignificant for federal estate tax purposes that the decedent, a non-resident alien, carried out his purposes within the particular legal means and juridical concepts which were recognized in his own country (and which create particular and definite legal effect there). The tax court stated that it was more important to consider the method and technique that the decedent would have had available in the United States in order to accomplish his basic purposes and concluded that the foundations should be treated as revocable trusts because they were created by the decedent in order to provide for his children. Moreover, it held that in any event, regardless of the classification of the foundations, taxability followed from the decedent's power to alter, amend and to revoke the transfer.

The Court of Appeals agreed with the conclusion of the Tax Court and held that sections 862(b) and $811(\mathrm{~d})^{11}$ are not limited to trust arrangements but expressly refer to the broad category of all 'revocable transfers', as shown by the specific references to 'a transfer... by trust or otherwise'. Agreeing with the decision of the Tax Court it held that section 811(d) is directed at transfers which are valid under state law but in which the taxpayer has retained control over the ultimate enjoyment of the property up to the date of his death. Where this control exists, the value of the property is includible in the estate regardless of any unique or unusual mode of transfer that may have been devised.

\section{(v) Analysis of the decision}

The statement of the Court of Appeals, namely that transfers of US situs assets which are valid under foreign law but which are revocable by the taxpayer result in such property being subject to US estate taxes, highlights

10 Now Internal Revenue Code of 1954 ss2038 and 2104(b) 11 Id. 
a trap for unwary foreign taxpayers, who like the taxpayers in Swan, may not be aware of these estate tax consequences.

Apart from this conclusion, the facts and circumstances of the two Estate of Swan cases are so unique that the classification of these foundations as revocable trusts would probably have been limited to the particular case. $^{12}$

\section{Classification of private foundations under current law}

\section{(i) The statutory framework}

While the law governing the private foundation determines the rights, duties and benefits of the foundation, its founder and its beneficiaries, the appropriate classification of private foundations for federal tax purposes is a matter of US federal tax law and does not depend on how the private foundation is treated under local law. ${ }^{13}$ The fact that a private foundation would be treated as a legal entity in a civil law country is therefore irrelevant for its classification under US federal tax law.

Can a private foundation therefore elect its classification for US federal tax purposes under the Check-theBox Regulations? ${ }^{14}$ The answer to this question depends on the character of a private foundation, because the Check-the-Box Regulations only apply to business entities. The Entity Classification Regulations provide that the determination whether a foundation is to be treated for tax purposes as a trust or as an association depends on whether there are associates and an objective to carry on business and distribute the gains therefrom. ${ }^{15}$ The Regulations distinguish between an 'ordinary' trust, which has no associates and business purpose and is therefore classified as a trust, and a 'business' trust, which has associates, because the

12 In fact, the two foundations set up on instruction of the decedent were so seriously flawed that it is likely that they would not have been regarded as valid foundations by a civil law court either: both foundations were originally set up as Swiss family foundations. However, the restrictions imposed by Art. 335 of the Swiss Civil Code on the acceptable purposes of such Swiss family foundations were completely ignored, so that the foundations would have been treated as 'Familienfideikommisse', with the result that they would have been void.

13 Section 301.7701-1(a)(1).

14 Section 301.7701-3.

15 Section 301.7701-4. beneficiaries created it, and a business purpose, because of its profit-making orientation. ${ }^{16}$

(ii) Definition of an 'ordinary' trust

An 'ordinary' trust is an arrangement through which trustees protect and conserve property for the benefit of the trust beneficiaries. ${ }^{17}$ This is the type of entity that one normally thinks of when the word 'trust' is used, particularly with respect to fiduciary and estate planning. ${ }^{18}$ The beneficiaries usually do not participate in planning the trust or drafting the trust instrument. This arrangement is not taxed as an association as such a trust has neither associates, because the beneficiaries are not involved in the trust management, nor a business purpose, because the trustees only protect and conserve property rather than use it to carry on a business. ${ }^{19}$

(iii) Determining the presence of 'associates'

The Supreme Court held that the term 'association' implies the entering into a joint enterprise for the transaction of business. It stated that this is not a characteristic of an ordinary trust, by which particular property is conveyed to a trustee or is to be held by the settlor, on specified trusts, for the benefit of named or described persons. ${ }^{20}$ Beneficiaries of an ordinary trust do not ordinarily plan a common effort nor enter into an association for the conduct of a business enterprise. $^{21}$

In deciding whether an entity has associates, a court reviews both the trust instrument and the actions of the beneficiaries and determines (a) whether the beneficiaries have voluntarily associated themselves and (b) whether they have participated actively in operating the trust. ${ }^{22}$ Under the Regulations, the presence of either factor qualifies the participants as associates.

The same tests, which apply to determine whether a trust has associates, must be applied to determine, whether a private foundation has associates. Typically, beneficiaries of private foundations do not have an active role in the creation of the entity. They are simply

16 Section 301.7701-4(a) and (b).

17 Section 301.7701-4(a).

18 US Tax Classification of Trusts: when is a trust not a trust? E. Sanborn, Estate Planing, September 2004.

19 Determining the taxable status of trusts that run businesses, Colleen J. Doolin, Cornell Law Review, August 1985-70 Cornell L. Rev. 1143.

20 Absent a statutory definition of 'associates' the meaning of this term is construed in accordance with the precedent established in the Supreme Court decision Morrissey $v$ Commissioner of Internal Revenue, the leading case on the classification of an entity as an 'association'.

21296 US 344.

2270 Cornell L. Rev. 1143 
appointed by the founder and often they just have a contingent interest and not a beneficial entitlement as long as the founder lives. ${ }^{23}$ Consequently, beneficiaries of private foundations are not associates within the meaning of section 301.7701-4(a).

(iv) Determining the presence of a 'business purpose'

In determining whether a trust has a business purpose, courts have primarily focused on the language of the trust instrument and not on the actual activities of the entity. The US Supreme Court held that 'the parties are not at liberty to say that their purpose was other or narrower than that which they formally set forth in the instrument under which their activities were conducted'. ${ }^{24}$ The Court's rationale was that the level of activity authorized by the trust instrument retains its vitality no matter how long the powers lie dormant. ${ }^{25}$ For example, the trust instrument in Morrissey authorized the trustees to conduct business, and the Court found a business purpose even though the trustees had engaged in no business during the taxable year. ${ }^{26}$

(v) Conclusion: private foundations are typically classified as trusts

Individuals setting up private foundations primarily wish to hold their bankable assets ${ }^{27}$ in a confidential structure during their lifetime and to have these assets transferred to their children in a swift and confidential process upon their death. The typical private foundation does therefore not have a business purpose and would thus be classified as a trust under US federal tax law.

If, however, a private foundation is carrying on a profit-making business, which normally would have been carried out through business organizations that are classified as corporations or partnerships under the Internal Revenue Code, then it will be treated as a business trust. ${ }^{28}$ Even if the corpus of such a private foundation is not supplied to the beneficiaries, it will still be classified as a business entity rather than as trust. ${ }^{29}$ The consequence of this

\footnotetext{
23 A reason for not entitling beneficiaries to a benefit prior to the founder's death or mental incapacitation is that this significantly reduces the foundation council's liability towards such individuals. This mechanism allows professional board members to enter into investment transactions the liability risk of which would otherwise be too high.

24 Helvering $v$ Coleman-Gilbert Associates, 296 US 365, 369 (1935).

2570 Cornell L. Rev. 1143.

26 Id.

27 Such as cash, stocks, bonds, structured products/derivatives, money market investments or even alternative investments like private equity.

28 The Swiss Business Foundations, discussed in detail in the article written by Paltzer/Schmutz in this same publication, are examples of such entities.
}

29 Section 301.7701-4(b). classification is that it can elect its classification for federal tax purposes pursuant to the Check-the-Box Regulations. $^{30}$

\section{Classification as domestic or foreign trust}

The term 'foreign trust' means any trust other than a domestic trust. ${ }^{31}$ A trust is a domestic trust, if '(i) a court within the United States is able to exercise primary supervision over the administration of the trust, and (ii) one or more United States persons have the authority to control all substantial decisions of the trust'. ${ }^{32}$ The Regulations refer to the requirements as the 'court test' and the 'control test. ${ }^{33}$ Whether the court test and the control test are met is determined by the terms of the trust instrument, ie in case of a private foundation by its statutes and by-laws and the applicable law. ${ }^{34}$

\section{(i) Court test}

For purposes of the court test, a court is able to exercise primary supervision if it has the authority under the applicable law to issue orders or judgments resolving issues concerning the administration of the trust. ${ }^{35}$ The term 'primary supervision' means that a court has or would have the authority to determine substantially all issues regarding the administration of the entire trust. ${ }^{36}$ The term 'administration' means in this context the carrying out of duties imposed on a fiduciary by the terms of the trust instrument and the applicable

30 Pursuant to section 301.7701-3(a), a business entity that is not classified as a corporation (which the private foundation is not) is an eligible entity that can elect its classification for federal tax purposes. An eligible entity with at least two members can elect to be classified as either an association (and thus a corporation under section 301.7701-2(b)(2) or a partnership, and an eligible entity with a single owner can elect to be classified as an association or to be disregarded as an entity separate from its owner. The regulations provide that unless the private foundation elects otherwise, it is:

(A) a partnership if it has two or more members and at least one member does not have limited liability;

(B) an association if all members have limited liability; or

(C) disregarded as an entity separate from its owner if it has a single owner who does not have limited liability.

A member of a foreign eligible entity has limited liability if the member has no personal liability for the debts of or claims against the entity by reason of being a member. As the beneficiaries of a private foundation are not liable for the foundation's debts, a Business Foundation with more than one member that does not opt to make an election will be treated as an association and will thus be subject to the corporate tax rules.

31 Section 7701(a)(31) and s301.7701-7(a)(2).

32 Section $7701(\mathrm{a})(30)(\mathrm{E})$.

33 Section 301.7701-7(a)(1).

34 Section 301.7701-7(b)

35 Section 301.7701-7(c)(3)(iii)

36 Section 301.7701-7(c)(3)(iv). 
law, including the keeping of books and records, filing of tax returns, defending the trust from suits by creditors and determining the amount and timing of distributions. ${ }^{37}$

Whether a private foundation satisfies the court test depends therefore on its statutes and by-laws and the applicable law. In Liechtenstein, for example, family and mixed foundations, which are the two most common private foundations, are under Liechtenstein court supervision. ${ }^{38}$ A US court would therefore have no authority under Liechtenstein law to render orders or judgments to resolve issues concerning the administration of the foundation. Consequently, Liechtenstein foundations will fail the court test.

\section{(ii) Control test}

Under the control test, a trust can be domestic only, if 'one or more United States persons have the authority to control all substantial decisions of the trust'. ${ }^{39}$ The term substantial decisions refers to those decisions which persons are authorized or required to make under the terms of the trust instrument and applicable law and that are not ministerial. ${ }^{40}$ Substantial decisions include decisions concerning the timing and the amount of distributions, the selection of a beneficiary, allocation of receipts to income or capital, termination of the trust, the removal, addition or replacement of a trustee and investments.

(iii) Conclusion

A private foundation can be structured in such a way that the founder, as the holder of the founder's rights, is entitled to make such decisions that the control test would be met, if a US person were the founder and the holder of such founder's rights. As, however, both the control test and the court test must be met at the same time, a private foundation will be treated as a foreign trust for US federal income tax purposes.

\section{The US taxation of private foundations}

As a foreign trust, a private foundation is treated for federal income tax purposes as a non-resident alien individual who is not present in the United States at any time. ${ }^{41}$

\footnotetext{
37 Section 301.7701-7(c)(3)(v).

38 Article 567 (1) PGR.

39 Section 7701(a)(30)(E).

40 Section 301.7701-7(d)(1)(ii).

41 Section 301.7701-7(a)(3) and section 641(b).
}

Consequently, it is only subject to US federal income tax on

- gross income that is effectively connected with the conduct of a trade or business within the United States and

- gross income derived from sources within the US that is not effectively connected with the conduct of a trade or business within the United States, such as interest and dividends from US corporations, rental income and royalties from property located in the US and gains from the disposition of US real estate.

As non-resident aliens, private foundations are subject to US federal income tax in the same manner as US citizens and residents on income which is effectively connected with the conduct of trade or business within the United States. ${ }^{42}$ The term 'trade or business within the United States' does not include trading in stocks and securities by the private foundation for its own account. ${ }^{43}$ In computing its taxable income, the private foundation is entitled to reduce its gross income by the deductions that are connected with such income from sources within the United States. ${ }^{44}$ The taxable income so determined is then subject to the normal tax rates applicable to trusts.

As non-resident aliens, private foundations are also subject to US federal income tax on some types of recurring investment income. A tax of 30 percent is imposed on amounts received by the private foundation from sources within the United States as interest, dividends, rents and royalties (but not on portfolio interest). ${ }^{45}$ No deductions are permitted against these types of income so that they are generally subject to a 30 percent tax on the gross amount of the distribution, unless the distributions are income effectively connected with the conduct of a US trade or business.

By virtue of section $641(\mathrm{~b})$, a private foundation is not subject to tax on gains derived from sources within the United States from the sale of capital assets, except to the extent that the private foundation's gains result from the disposition of 'United States real property interests', ie from the sale of US real property or the stock of certain real property holding companies. ${ }^{46}$ Such

\footnotetext{
42 Section $871(\mathrm{~b})$.

43 Section 864(b)(2)(A).

44 Section $1.873-1$

45 Section $871(\mathrm{a})$.

46 Section $897($ c) (1)
} 


\section{Classification of private foundations for US federal income tax purposes}

gains from the disposition of 'United States real property interests' are treated as income that is effectively connected with a US trade or business. ${ }^{47}$

\section{Conclusion}

This article has sought to provide an overview on the decisive factors, which determine how a foreign private foundation is classified for US federal income tax purposes. Since this determination depends on factors, which may vary considerably from one foundation to the other, each private foundation should be analysed individually based on its governing documents and the applicable law in order to reach a conclusion regarding its classification. Typically, the result of this analysis will be that a private foundation will be treated as a foreign trust for US federal income tax purposes.

doi:10.1093/tandt/ttm012 Advance Access publication 27 March 2007

\section{Lic.iur. Patrick Schmutz, LLM (Taxation)}

Niederer Kraft \& Frey, Attorneys at Law

Bahnhofstrasse 13

CH-8001 Zurich

Switzerland

Tel: +41 588008000

Fax: +4158 8008080

Email: patrick.schmutz@nkf.ch www.nkf.ch 